\title{
Some physico-chemical properties, fatty acid compositions, macro-micro minerals and sterol contents of two variety tigernut tubers and oils harvested from East Mediterranean region
}

\author{
Erman DUMAN ${ }^{1 *}$
}

\begin{abstract}
This research on Yellow sugar and Honey tuber varieties tigernut tubers' oils physico-chemical properties were investigated to collected from Adana province in Turkey. The 1000 seed weight, width, length, moisture, ash and ascorbic acid values of yellow sugar and honey wax tubers were established as 343,496 and 327,524 g, 7.61 and $8.76 \mathrm{~mm}, 17.07$ and $15.23 \mathrm{~mm}, 6.41$ and $6.45 \%$, 1.19 and $1.38 \%$ and 67.34 and $58.81 \mathrm{mg} / \mathrm{kg}$, respectively. Free fatty acidity, peroxide values, refractive index, density, iodine number, total sterol, saponifiable matter, unsaponifiable matter, mineral values of yellow sugar and honey tuber tigernut oils were determined. The palmitic, stearic, oleic and linoleic acid contents of yellow sugar and honey tuber oils were determined as 13.02 and 12.76, 3.92 and 3.94, 69.34 and 69.91, and 11.93 and 11.80\%, respectively. Campesterol, sitigmasterol and $\beta$-sitosterol contents of yellow sugar and honey tuber tigernut oils were determined. According to results, chufa tubers have high oil, oleic acid, sterol and some minerals suggest that these tubers may be very useful effect on human health and tuber oils can be use in the vegatable oil industry.
\end{abstract}

Keywords: tigernut; variety; minerals; fatty acid composition; sterols; food.

Practical Application: Two types of tigernut tubers nutritional properties and detail oil specifications.

\section{Introduction}

Tigernut (Cperus esculentus L.) widely cultivates in some countries around the world for example Greece, Italy, Turkey, Israel and West Africa countries (Temple et al., 1989; Eteshola \& Oraedu, 1996). Tigernut called as chufa, earth almond is an edible perennial plant (Özcan et al., 2010; Yoon, 2015). Tigernut seed has abundant in oil amount (17-33\%) and it is a potential new source for edible oil (Addy \& Eteshola, 1984; Sánchez-Zapata et al., 2012; Yoon, 2015). Futhermore, Chufa oil can be used for many industrial purposes (Barninas et al., 2001). Tigernut has important components in terms of nutritionally such as oil amount, antioxidant matters and it used as raw, roasted, dried, baker (Belewu \& Belewu, 2007; Oladele \& Aina, 2007). Tuber is used in many for food, such as powder, delicious nut-like flavour, beverage. In addition it is used in cooking and in making soap (Facciola, 1990). Tigernut oils have contetnt rich palmitic and oleic acids in terms of fatty acid composition (Eteshola \& Oraedu, 1996; Yoon, 2015). In addition, tiger nut tubers have been used in the field of health against various diseases such as aphrodisiac, carminative, diuretic (Chopra et al., 1986). The aim of this researh is to determine from wide angle some physical properties, fatty acid composition, sterol contents and mineral contents of chufa tuber and oils harvested from East Mediterranean region in Turkey.

\section{Materials and methods}

\subsection{Material}

The chufa seeds (Cyperus esculentus L.) varieties used in the research were provided from Eastern Mediterranean Agricultural Research Institute in Adana province in Turkey in 2017. For this purpose, $10 \mathrm{~kg}$ of chufa seed collected from in Adana province region were kept in air-permeable cardboard boxes to prevent mold and sweating. All samples dried for one week on the sun. In addition, samples variety were identified as Sarı șeker (yellow sugar) and Bal yumru (honey tuber) varieties by Adana Eastern Mediterranean Agricultural Research Institute.

\subsection{Physical analysis}

Tuber weight

For each species, a certain number of both chufa tubers were removed and weighed on a scale with a precision of $0.01 \mathrm{~g}$ counted to 1000 seeds (Türk Standartları Enstitüsü, 2014).

\section{Tuber dimensions}

In the large, medium and small sized tubers, width and length measurements were made with digital calipers and average of the results was taken as $\mathrm{mm}$. 


\section{Moisture}

Approximately $10 \mathrm{~g}$ of the sample was previously dried at $105^{\circ} \mathrm{C}$ and weighed in intact vessels. After weighing, the product at $105^{\circ} \mathrm{C}$ was dried to constant weight. The amount of moisture was calculated as \% weight loss (American Association of Cereal Chemists International, 1999).

Ash

Approximately $3 \mathrm{~g}$ of sample from each sample was previously dried at $105{ }^{\circ} \mathrm{C}$ and weighed to the ash crucible cooled. It was then placed in the ash oven at $700{ }^{\circ} \mathrm{C}$ and the samples were expected to fully sideways (until the ash was completely whitened). The time for complete combustion of the samples ranged from 5 to 6 hours. The amount of ash was calculated as percent (American Association of Cereal Chemists International, 1999).

\section{Oil extraction}

About 5-10 g of dried, ground tigernut tuber was placed in the cartridge and the cartridge was placed in the extractor. By connecting the balloon and the extractor, the petroleum ether was put on the cartridge until it was able to circulate and was removed after 6 hours. The petroleum ether was distilled off. The glass balloon was heated to $103{ }^{\circ} \mathrm{C}$ for a maximum of 3 hours and then cooled in a desicator and weighed then it was calculated as percent oil value based on the dry matter (Uylaşer \& Başoğlu, 2000).

\section{Determination of ascorbic acid}

The ascorbic acid determination was carried out according to the method reported by Vázquez-Oderiz et al. (1994). For determination of ascorbic acid used below conditions with HPLC.

Instrument: SHIMADZU GC-2025

Injection volume: $10 \mu \mathrm{L}$

Reverse phase separation: Zorbax ODS $(4.6 \times 250 \mathrm{~mm}, 5 \mu)$

Flow rate: $0.5 \mathrm{~mL} / \mathrm{min}$

Detection wave length: $245 \mathrm{~nm}$

\section{Determination of mineral contents}

The mineral contents determination was carried out according to the method reported by Skujins (1998). After the sample burning and preparation steps according to the specified method. Analysis was performed using a ICP-AES (Varian-Vista). RF Power used 0.7-1.5 kw (1,2-1,3 kw for Axial). Plasma gas flow rate used (Ar): 10.5-15 L/min (Skujins, 1998).

\section{Physico-chemical analysis of oils}

Tigernut tuber oils some physical and chemical analysis; density, free fatty acidity, peroxide value, iodine value, refractive index, saponification value, unsaponification matter, and total sterol values were analysed according to AOCS methods (American Oil Chemists' Society, 1998; Food Safety and Standards Authority of India, 2015).

\section{Oils colour}

15-20 mL Tigernut tubers oils were filtered by using Whatman (No. 22) paper, and placed into separate containers of 1 inch. The color of oils were measured by Lovibond PFX tintometer 880 for $22^{\circ} \mathrm{C}$. The measurements of the color of each oil was carried out through three different reading (American Oil Chemists' Society, 2017)

\section{Fatty acid composition}

The fatty acid composition determination was carried out according to the method reported by Hișıl (1998). After the samples methyl esters (FAME) and preparation steps according to the specified method. For determiation of fatty acid composition used below conditions with GC.

\section{Working condition of gas chromotography}

Instrument: SHIMADZU GC-2025

Silica capillary column (RTX-2330): (100 m × 0.25 mm i.d.; film thickness 0.20 micrometer)

Support material: Chromosorb W(AW-DMCS) (60-80 mesh)

Dedector: FID (Flame Ionization Detector)

Temperature

$$
\begin{aligned}
& \text { Column: } 180^{\circ} \mathrm{C} \\
& \text { Enjector: } 200{ }^{\circ} \mathrm{C} \\
& \text { Dedector: } 200^{\circ} \mathrm{C}
\end{aligned}
$$

Flow

Carrier gas $\left(\mathrm{N}_{2}\right): 30 \mathrm{~mL} / \mathrm{min}$.

Combustible gas $\left(\mathrm{H}_{2}\right): 28 \mathrm{~mL} / \mathrm{min}$.

Dry air: $220 \mathrm{~mL} / \mathrm{min}$.

Printer: Chromatopac CR 6A (Shimadzu)

Enjection volume: $1 \mu \mathrm{L}$

\section{Sterol composition}

The sterol composition determination was carried out according to the method reported by Phillips et al. (2005).

Working conditions of gas chromatography;

Instrument: Agilent GC

Silica capillary column $(30 \mathrm{~m} \times 0.32 \mathrm{~mm}$ i.d.; film thickness 0.25 micrometer). 


\section{Dedector: FID (Flame Ionization Detector)}

Temperature

Coloum: The column temperature was increased from 0 to $60{ }^{\circ} \mathrm{C}(2 \mathrm{~min})$ and then from 60 to $220{ }^{\circ} \mathrm{C}(18 \mathrm{~min})$ and finally held at $220^{\circ} \mathrm{C}(35 \mathrm{~min})$.

Flow

Carrier gas (He): $45 \mathrm{~mL} / \mathrm{min}$.

Combustible gas $\left(\mathrm{H}_{2}\right): 45 \mathrm{~mL} / \mathrm{min}$.

Dry air: $45 \mathrm{~mL} / \mathrm{min}$.

Enjection volume: $1 \mu \mathrm{L}$

\subsection{Statistical analysis}

Statistical analyzes were performed using SPSS 17.0 for Windows. One-way ANOVA was used for analysis of variance of the results of the research, and importance scores between the mean were determined by Duncan Multiple Comparison Test. All analyses were carried out three times and the results are mean \pm standard deviation of independent tigernut oils (Püskülcü \& İkiz, 1998).

\section{Results and discussion}

The physico-chemical properties of yellow sugar and honey tuber tigernut samples are given in Table 1. Yellow sugar and honey tuber tigernut samples contained $22.59 \%$ and $21.52 \%$ oil, respectively. The 1000 seed weight, width, length, moisture, ash and ascorbic acid values of yellow sugar and honey tubers were established as 343.496 and $327.524 \mathrm{~g}, 7.61$ and $8.76 \mathrm{~mm}$, 17.07 and $15.23 \mathrm{~mm}, 6.41$ and $6.45 \%, 1.19$ and $1.38 \%$ and 67.34 and $58.81 \mathrm{mg} / \mathrm{kg}$, respectively.

The physico-chemical properties of yellow sugar and honey tuber tigernut oil samples are given in Table 2. Free fatty acidity, peroxide values, refractive index, density, iodine number, total sterol, saponifiable matter, unsaponifiable matter values of yellow sugar and honey tuber tigernut oils were determined as 2.69 and $3.25 \%, 20.43$ and $14.13 \mathrm{meqO}_{2} / \mathrm{kg}, 1.4624$ and $1.4680 \mathrm{n}^{20}{ }_{\mathrm{D}^{\prime}}$ 0.899 and $0.893,81.10$ and $81.41,2612$ and $2012 \mathrm{mg} / \mathrm{kg}$, 164.76 and $158.98 \mathrm{mg} \mathrm{KOH} / \mathrm{g}$ and 0.59 and $0.40 \%$, respectively. Oderinde \& Tairu (1988) reported 22.6-22.9\% oil, 5.3-6.9 meqO $_{2} / \mathrm{kg}$ peroxide value, $80.2-83.3$ iodine number, 1.4674 refractive index for tigernut oil.

Mineral contents of yellow sugar and honey tuber tigernuts are presented in Table 3. P, K, Ca, Mg and S contents of tubers were the major minerals of both yellow sugar and honey tuber tigernuts samples. While yellow sugar contains $13443 \mathrm{mg} / \mathrm{kg} \mathrm{P}$, $8673 \mathrm{mg} / \mathrm{kg} \mathrm{K}, 1159 \mathrm{mg} / \mathrm{kg} \mathrm{Ca}, 1203 \mathrm{mg} / \mathrm{kg} \mathrm{Mg}$ and $1297 \mathrm{mg} / \mathrm{kg} \mathrm{S}$, honey tuber tigernut contained $14615 \mathrm{mg} / \mathrm{kg}$ P, $7456 \mathrm{mg} / \mathrm{kg} \mathrm{K}$, $1648 \mathrm{mg} / \mathrm{kg} \mathrm{Ca}, 1431 \mathrm{mg} / \mathrm{kg} \mathrm{Mg}$ and $1266 \mathrm{mg} / \mathrm{kg} \mathrm{S}$. In addition, both yellow sugar and honey tuber tigernut tubers contained $85 \mathrm{mg} / \mathrm{kg}$ and $104 \mathrm{mg} / \mathrm{kg} \mathrm{Fe}, 8.6 \mathrm{mg} / \mathrm{kg}$ and $8.6 \mathrm{mg} / \mathrm{kg} \mathrm{Cu}$, $4.9 \mathrm{mg} / \mathrm{kg}$ and $6.9 \mathrm{mg} / \mathrm{kg} \mathrm{Mn}, 10.3 \mathrm{mg} / \mathrm{kg}$ and $10.0 \mathrm{mg} / \mathrm{kg} \mathrm{Zn}$ and $2.9 \mathrm{mg} / \mathrm{kg}$ and $3.2 \mathrm{mg} / \mathrm{kg} \mathrm{B}$, respectively. When results were compared, some micro and macro elements; as $\mathrm{P}, \mathrm{Ca}, \mathrm{Mg}, \mathrm{Fe}$, $\mathrm{Mn}$ and $\mathrm{B}$ were found in honey tuber tigernut tubers higher than yellow sugar tigernut tubers. Also, Glew et al. (2006) reported 52.9 ug/g Fe, 188 ug/g Ca, 763 ug/g Mg, 11.2 ug/g Zn, $55732 \mathrm{ug} / \mathrm{g} \mathrm{K}$.

Tocopherol amounts of yellow sugar and honey tuber tigernut oils are are shown in Table 4 . $\alpha$-tocopherol and $\beta$-tocopherol were the key tocopherol of tigernut tuber oils. The tocopherol amounts of tuber oils changed depending on varieties. The a-tocopherol and $\beta$-tocopherol contents of yellow sugar and honey tuber oils were determined as 17.54 and 7.04, 15.89 and $9.44 \mathrm{mg} / 100 \mathrm{~g}$, respectively. When results were compared, $\beta$-tocopherol amounts were found in honey tuber tigernut tubers higher than yellow sugar tigernut tubers. Yeboah et al. (2012) were determined $\alpha$-tocopherol (86.73) and $\beta$-tocopherol $(33.37 \mu \mathrm{g} / \mathrm{g})$ for tigernut oil tocopherol amounts.

Table 1. Physico-chemical properties of yellow sugar and honey tuber tigernut tubers.

\begin{tabular}{|c|c|c|c|c|c|c|c|c|c|}
\hline Variety & $\begin{array}{l}1000 \text { tuber } \\
\text { weight (g) }\end{array}$ & Width (mm) & Length (mm) & Moisture (\%) & Ash (\%) & $\begin{array}{c}\text { Ascorbic acid } \\
(\mathrm{mg} / \mathrm{kg})\end{array}$ & Oil (\%) & $\begin{array}{c}\text { Free fatty } \\
\text { acidity (\%) }\end{array}$ & $\begin{array}{c}\text { Peroxide } \\
\text { value } \\
\left(\mathrm{meqO}_{2} / \mathrm{kg}\right)\end{array}$ \\
\hline $\begin{array}{l}\text { Yellow } \\
\text { sugar }\end{array}$ & $343.49 \pm 1.18 \mathrm{a}$ & $7.61 \pm 0.31 b$ & $17.07 \pm 0.32 \mathrm{a}$ & $6.41 \pm 1.21 \mathrm{ab}$ & $1.19 \pm 0.36 b$ & $67.34 \pm 1.48 \mathrm{a}$ & $22.59 \pm 2.45 a$ & $2.69 \pm 0.76 b$ & $20.43 \pm 1.39 a$ \\
\hline $\begin{array}{l}\text { Honey } \\
\text { tuber }\end{array}$ & $327.52 \pm 2.37 b$ & $8.76 \pm 0.23 a$ & $15.23 \pm 0.15 b$ & $6.45 \pm 0.97 a$ & $1.38 \pm 0.41 \mathrm{a}$ & $58.81 \pm 1.57 b$ & $21.52 \pm 1.29 b$ & $3.25 \pm 0.84 a$ & $14.13 \pm 1.45 b$ \\
\hline
\end{tabular}

\pm mean standard deviation. Values within each column followed by different letters are significantly different $(\mathrm{p}<0.05)$.

Table 2. Physico-chemical properties of yellow sugar and honey tuber oils tigernut tubers.

\begin{tabular}{|c|c|c|c|c|c|c|c|c|c|}
\hline \multirow{2}{*}{ Variety } & \multirow{2}{*}{$\begin{array}{l}\text { Refractive index } \\
\quad\left(20^{\circ} \mathrm{C}\right)\end{array}$} & \multirow{2}{*}{$\begin{array}{l}\text { Density } \\
\left(20^{\circ} \mathrm{C}\right)\end{array}$} & \multirow{2}{*}{$\begin{array}{l}\text { Iodine } \\
\text { number }\end{array}$} & \multirow{2}{*}{$\begin{array}{l}\text { Total sterol } \\
(\mathrm{mg} / \mathrm{kg})\end{array}$} & \multirow{2}{*}{$\begin{array}{c}\text { Saponifiable } \\
\text { number } \\
(\mathrm{mgKOH} / \mathrm{g})\end{array}$} & \multirow{2}{*}{$\begin{array}{c}\text { Unsaponifiable } \\
\text { matter } \\
(\%)\end{array}$} & \multicolumn{3}{|c|}{ Color } \\
\hline & & & & & & & Red & Yellow & Blue \\
\hline $\begin{array}{l}\text { Yellow } \\
\text { sugar }\end{array}$ & $1.4624 \pm 0.0034 \mathrm{ab}$ & $0.899 \pm 0.006 a$ & $81.10 \pm 2.56 \mathrm{ab}$ & $2612 \pm 12.57 \mathrm{a}$ & $164.76 \pm 13.45 a$ & $0.59 \pm 0.09 a$ & $4.0 \pm 0.01 a$ & $72.9 \pm 1.27 \mathrm{a}$ & $2.9 \pm 0.3 a$ \\
\hline $\begin{array}{l}\text { Honey } \\
\text { tuber }\end{array}$ & $1.4680 \pm 0.0021 \mathrm{a}$ & $0.893 \pm 0.003 \mathrm{ab}$ & $81.41 \pm 3.84 a$ & $2012 \pm 28.36 b$ & $158.98 \pm 4.86 b$ & $0.40 \pm 0.03 b$ & $2.7 \pm 0.03 b$ & $70.6 \pm 1.11 b$ & $0.6 \pm 0.1 b$ \\
\hline
\end{tabular}

\pm mean standard deviation. Values within each column followed by different letters are significantly different $(\mathrm{p}<0.05)$. 
Table 3. Macro and micro element contents of yellow sugar and honey tuber tigernuts tubers (mg/kg).

\begin{tabular}{|c|c|c|c|c|c|c|c|c|c|c|}
\hline Variety & $\mathrm{P}$ & $\mathrm{K}$ & $\mathrm{Ca}$ & $\mathrm{Mg}$ & $\mathrm{S}$ & $\mathrm{Fe}$ & $\mathrm{Cu}$ & $\mathrm{Mn}$ & B & $\mathrm{Zn}$ \\
\hline $\begin{array}{l}\text { Yellow } \\
\text { sugar }\end{array}$ & $13443 \pm 27.58 b$ & $8673 \pm 46.11 a$ & $1159 \pm 13.27 b$ & $1203 \pm 10.23 b$ & $1297 \pm 16.82 \mathrm{a}$ & $85 \pm 3.28 b$ & $8.6 \pm 0.9 a$ & $4.9 \pm 0.3 b$ & $2.9 \pm 0.3 b$ & $10.3 \pm 0.7 a$ \\
\hline $\begin{array}{l}\text { Honey } \\
\text { tuber }\end{array}$ & $14615 \pm 104.12 \mathrm{a}$ & $7456 \pm 28.96 b$ & $1648 \pm 9.85 a$ & $1431 \pm 11.87 \mathrm{a}$ & $1266 \pm 14.76 \mathrm{ab}$ & $104 \pm 7.56 a$ & $8.6 \pm 1.1 \mathrm{a}$ & $6.9 \pm 0.7 a$ & $3.2 \pm 0.9 \mathrm{a}$ & $10.0 \pm 1.3 \mathrm{ab}$ \\
\hline
\end{tabular}

\pm mean standard deviation. Values within each column followed by different letters are significantly different $(\mathrm{p}<0.05)$.

Table 4. Tocopherol contents of yellow sugar and honey tuber tigernuts tubers $(\mathrm{mg} / 100 \mathrm{~g})$.

\begin{tabular}{lrr}
\hline \multicolumn{1}{c}{ Tocopherol } & Yellow sugar & Honey tuber \\
\hline a-tocopherol & $17.54 \pm 0.07 \mathrm{a}$ & $15.89 \pm 0.10 \mathrm{~b}$ \\
$\beta$-tocopherol & $7.04 \pm 0.13 \mathrm{a}$ & $9.44 \pm 0.09 \mathrm{~b}$ \\
\hline
\end{tabular}

\pm mean standard deviation. Values within each column followed by different letters are significantly different $(\mathrm{p}<0.05)$.

Table 5. Fatty acid composition of tigernut (Cyperus esculentus L.) tuber oils tuber (\%).

\begin{tabular}{lcc}
\hline \multicolumn{1}{c}{ Fatty acids } & Yellow sugar & Honey tuber \\
\hline Myristic & $0.26 \pm 0.05 \mathrm{a}$ & $0.07 \pm 0.01 \mathrm{~b}$ \\
Myristoleic & $0.02 \pm 0.00 \mathrm{a}$ & $0.01 \pm 0.00 \mathrm{a}$ \\
Palmitic & $13.02 \pm 0.17 \mathrm{a}$ & $12.76 \pm 0.28 \mathrm{~b}$ \\
Palmiteloic & $0.06 \pm 0.01 \mathrm{a}$ & $0.06 \pm 0.01 \mathrm{a}$ \\
Heptadecanoic & $0.04 \pm 0.01 \mathrm{ab}$ & $0.05 \pm 0.03 \mathrm{a}$ \\
Stearic & $3.92 \pm 0.27 \mathrm{a}$ & $3.94 \pm 0.56 \mathrm{a}$ \\
Oleic & $69.34 \pm 0.31 \mathrm{a}$ & $69.91 \pm 0.63 \mathrm{a}$ \\
Linoleic & $11.93 \pm 0.44 \mathrm{a}$ & $11.79 \pm 0.56 \mathrm{ab}$ \\
Linolenic & $0.02 \pm 0.00 \mathrm{a}$ & $0.02 \pm 0.00 \mathrm{a}$ \\
¥-linolenic & $0.19 \pm 0.05 \mathrm{ab}$ & $0.22 \pm 0.07 \mathrm{a}$ \\
Arachidic & $0.59 \pm 0.09 \mathrm{a}$ & $0.58 \pm 0.44 \mathrm{ab}$ \\
Cis-11-eicosenoic & $* .23 \pm 0.07 \mathrm{a}$ & $0.22 \pm 0.09 \mathrm{ab}$ \\
Cis-11,14-eicosadienoic & $0.12 \pm 0.03 \mathrm{a}$ & $0.11 \pm 0.03 \mathrm{ab}$ \\
Cis-8,11,14-eicosatrienoic & $0.03 \pm 0.01 \mathrm{a}$ & $0.01 \pm 0.00$ \\
Arachidonic & $0.20 \pm 0.03 \mathrm{a}$ & $0.19 \pm 0.07 \mathrm{ab}$ \\
Lignoceric & $0.03 \pm 0.01 \mathrm{a}$ & $0.03 \pm 0.01 \mathrm{a}$ \\
Nervonic & &
\end{tabular}

\pm mean standard deviation. Values within each column followed by different letters are significantly different $(\mathrm{p}<0.05) ;{ }^{*}$ nondetectable.

Table 6. Sterol compositions of tigernut (Cyperus esculentus L.) tuber oils $(\mathrm{mg} / \mathrm{kg})$.

\begin{tabular}{lrc}
\hline \multicolumn{1}{c}{ Sterols } & Yellow sugar & \multicolumn{1}{c}{ Honey tuber } \\
\hline Delta 7 Avenasterol & $13.06 \pm 0.09 \mathrm{a}$ & $9.25 \pm 0.13 \mathrm{~b}$ \\
Delta 7 Stigmastenol & $23.24 \pm 0.11 \mathrm{a}$ & $17.10 \pm 0.09 \mathrm{ab}$ \\
Eritrodiol-Uvaol & $5.48 \pm 0.07 \mathrm{a}$ & $3.42 \pm 0.03 \mathrm{ab}$ \\
Campesterol & $427.58 \pm 1.17 \mathrm{a}$ & $337.01 \pm 0.98 \mathrm{a}$ \\
Cholesterol & $2.35 \pm 0.03 \mathrm{a}$ & $1.00 \pm 0.01 \mathrm{~b}$ \\
Stigmasterol & $575.42 \pm 1.18 \mathrm{a}$ & $426.14 \pm 1.23 \mathrm{~b}$ \\
Beta-sitosterol & $1559.39 \pm 2.57 \mathrm{~b}$ & $1212.05 \pm 1.78 \mathrm{a}$ \\
Brassicasterol & $5.48 \pm 0.07 \mathrm{~b}$ & $6.03 \pm 0.09 \mathrm{a}$ \\
\hline
\end{tabular}

\pm mean standard deviation. Values within each column followed by different letters are significantly different $(\mathrm{p}<0.05)$.
Fatty acid compositions of yellow sugar and honey tuber tigernut oils are presented in Table 5. Palmitic, stearic, oleic and linoleic acids were the key fatty acids of tigernut tuber oils. The fatty acid compositions of tuber oils changed depending on varieties. The palmitic, stearic, oleic and linoleic acid contents of yellow sugar and honey tuber oils were determined as 13.02 and $12.76,3.92$ and 3.94, 69.34 and 69.91, 11.93 and $11.80 \%$, respectively. Other fatty acids were found at minor levels, and under $<0.6 \%$.

Generally, peroxide value, density, total sterol, saponifiable matter and unsaponifiable matter values and color values of yellow sugar tigernut oil were found partly higher compared to results of honey tuber tigernut oil. This results were found to some similar with Muhammad et al. (2011) and El-Naggar (2016). Oderinde \& Tairu (1988) fatty acid composition reported 13.4-14.1\% palmitic acid, $0.2-0.3 \%$ palmitoleic acid, $3.0-3.3 \%$ stearic acid, $71.7-73.5 \%$ oleic acid, $8.7-9.1 \%$ linoleic acid, $0.4 \%$ linolenic acid, $0.2-0.5 \%$ arachidic acid. Tigernut oils fatty acid compositions were found similar with literatures (Oderinde \& Tairu, 1988; Özcan et al., 2010).

The sterol compositions of tigernut oils (yellow sugar and honey tuber varieties) are shown in Table 6. It was observed statistically significant differences between sterol contents of both tigernut oils $(\mathrm{p}<0.05)$ in Table 6 . When results were compared, total sterol amounts were found in yellow tuber tigernut tubers $(2612 \mathrm{mg} / \mathrm{kg})$ higher than honey sugar tigernut tubers $(2012 \mathrm{mg} / \mathrm{kg})$. Campesterol, stigmasterol and $\beta$-sitosterol contents of yellow sugar and honey tuber tigernut oils were determined as 427.58 and $337.01 \mathrm{mg} / \mathrm{kg}, 575.42$ and $426.14 \mathrm{mg} / \mathrm{kg}$ and 1559.39 and $1212.05 \mathrm{mg} / \mathrm{kg}$, respectively. Yeboah et al. (2012) said that dominated by $\beta$-sitosterol $(517.25 \mu \mathrm{g} / \mathrm{g})$ and stigmasterol $(225.25 \mu \mathrm{g} / \mathrm{g})$ for tigernut oil sterol composition.

Acid value that is used in the free fatty acidity measurement of the free fatty acid and an important quality parameter in the edible oil industry (Belewu \& Belewu, 2007; Muhammad et al., 2011). Peroxides are give an indication of the process of lipid peroxidation (Shaker et al., 2009). Özcan et al. (2010) determined as $78.0 \mathrm{mg} / \mathrm{kg}$ of chufa ascorbic acid cotent. In a research done in Egypt, Adel et al. (2015) reported that tigernut tuber contained $7.30 \%$ moisture, $22.14 \%$ oil and $4.33 \%$ crude protein. Also, Adejuyitan (2011) reported that tigernut contained 3.50-3.78\% moisture, $32.13-35.43 \%$ oil and $7.15-9.70 \%$ crude protein in Nigeria. The physico-chemical properties of taro and tigernut tubers showed partly differences depending on results of literature (Mokady \& Dolev, 1970; Arafat et al., 2009). These differences can be probably due to species, climatic factors, growing conditions, harvest time, location and analytical conditions. 
Ca contents of both tubers were found similar. Tubers were found abundant in some minerals such as $\mathrm{Ca}(100.0 \mathrm{mg} / 100 \mathrm{~g})$, Fe (4.12 mg/100 g), K (486.0 mg/100 g), Mg (94.4 mg/100 g), $\mathrm{Na}(34.3 \mathrm{mg} / 100 \mathrm{~g})$ and $\mathrm{P}(219.0 \mathrm{mg} / 100 \mathrm{~g})$ (Ekeanyanwu \& Ononogbu, 2010). Calcium, otassium and phosphorus are the major components of bone and teeth development. As bromine, cadmium, lead and lithium elements are very important for biological process (Macrae et al., 1993a). Cadmium is toxicological properties (Macrae et al., 1993b). These inorganic elements weren't found in this research. The key sterols were campesterol, sitigmasterol and $\beta$-sitosterol for both tigernut varieties's oils. Also, this study aims to contribute in terms of mineral components of these tubers and sterol components of tubers oils.

\section{Conclusion}

As a result, this study shows that the physical and chemical properties of the two different types of chufa tubers and oils can be different properties. These differences can be caused by growing conditions, environmental conditions. Also, in both cultivars oils were found to nutritive in terms of fatty acid and streol compositions. The high oil contents, some minerals, unsaturated fatty acids, and sterols suggest that this tuber and oil can be use in the food industry.

\section{Acknowledgements}

Also, the authors wish to thank to Afyon Kocatepe University and Eastern Mediterranean Agricultural Research Institute Staff in Adana province in Turkey. This study was supported by Afyon Kocatepe University Scientific Research Project (AKU-BAP, Afyonkarahisar-Turkey) and results were obtained from 18. Career. 111 project.

\section{References}

Addy, E. O., \& Eteshola, E. (1984). Nutritive value of a mixture of tiger nut tubers (Cyperus esculentus L.) and boabab seeds (Adansonia digidata L.). Journal of the Science of Food and Agriculture, 35(4), 437-440. http://dx.doi.org/10.1002/jsfa.2740350412.

Adejuyitan, J. A. (2011). Tigernut processing: its food uses and health benefits. American Journal of Food Technology, 6(3), 197-201. http:// dx.doi.org/10.3923/ajft.2011.197.201.

Adel, A. A. M., Awad, A. M., Mohamed, H. H., \& Iryna, S. (2015). Chemical composition, physicochemical properties and fatty acid profile of tigernut (Cyperus esculentum L.) seed oil as affected by different preparation methods. International Food Research Journal, 22, 1931-1938.

American Association of Cereal Chemists International - AACC. (1999). Approved methods of analysis. St. Paul: AACC.

American Oil Chemists' Society - AOCS. (1998). Offical methods and recommended practices of the AOCS. Champaign: AOCS.

American Oil Chemists' Society - AOCS. (2017). Offical methods and recommended practices of the AOCS (Method Cc 13b-45). Champaign: AOCS.

Arafat, S. M., Gaafar, A. M., Basuny, A. M., \& Nassef, S. L. (2009). Chufa tubers (Cyperus esculentus L.): as a new source of food. World Applied Sciences Journal, 7, 151-156.

Barninas, J. T., Maina, H. M., Tahir, S., Kubmarwa, D., \& Tsware, K. A. (2001). Preliminary investigation into the biofuel characteristics of tiger nut (Cyperus esculentus L.) oil. Bioresource Technology, 9(1), 87-89. http://dx.doi.org/10.1016/S0960-8524(01)00026-8.

Belewu, M. A., \& Belewu, K. Y. (2007). Comparative physic chemical evaluation of tiger nut, soy bean and coconut milk sources. International Journal of Agriculture and Biology, 5, 785-787.

Chopra, R. N., Nayar, S. L., \& Chopra, I. C. (1986). Glossary of Indian medicinal plants: including the supplement. New Delhi: Council of Scientific and Industrial Research.

Ekeanyanwu, R. C., \& Ononogbu, C. I. (2010). Nutritive value of Nigerian Tigernut (Cyperus esculentus L.). Agricultural Journal., 5(5), 297-302. http://dx.doi.org/10.3923/aj.2010.297.302.

El-Naggar, E. A. (2016). Physicochemical characteristics of Tiger nut tuber (Cyperus esculentus Lam) oil. Middle East Journal of Applied Sciences, 6(4), 1003-1011.

Eteshola, E., \& Oraedu, A. C. (1996). Fatty acid compositions of tigernut tubers (Cyperus esculentus L.), baobab seeds (Adansonia digitata L.), and their mixture. Journal of the American Oil Chemists' Society, 73(2), 255-257. http://dx.doi.org/10.1007/BF02523905.

Facciola, S. (1990). Cornucopia: a source book of edible plants. Vista: Kampong Publications.

Food Safety and Standards Authority of India - FSSAI. (2015). Manual of methods of analysis of foods food oils and fats. New Delhi: Ministry of Health and Family Welfare.

Glew, R. H., Glew, R. S., Chuang, L. T. Y., Huang, S., Millson, M., Constans, D., \& Vanderjagt, D. J. (2006). Amino acid, mineral and fatty acid content of pumpkin seeds (Cucurbita spp) and Cyperus esculentus nuts in the Republic of Niger. Plant Foods for Human Nutrition, 61(2), 51-56. http://dx.doi.org/10.1007/s11130-0060010-z. PMid:16770692.

Hışıl, Y. (1998). Enstrümantal gida analizleri-II (4th ed., Yayın, No. 45). Bornova: Ege Üniversitesi Mühendislik Fakültesi Ders Kitapları. In Turkish.

Macrae, R., Robinson, R. K., \& Sadler, M. J. (1993a). Encyclopaedia of food science, food technology and nutrition (Vol. 5, pp. 3126-3131). San Diego: Academic Press.

Macrae, R., Robinson, R. K., \& Sadler, M. J. (1993b). Encyclopaedia of food science, food technology and nutrition (Vol. 7, pp. 4593-4600). San Diego: Academic Press.

Mokady, S. H., \& Dolev, A. (1970). Nutritional evaluaion of tubers of Cyperus esculentus L. Journal of the Science of Food and Agriculture, 21(4), 211-214. http://dx.doi.org/10.1002/jsfa.2740210411. PMid:5430450.

Muhammad, N. O., Bamishaiye, E. B., Usman, L. A., Salawu, M. O., Nafiu, M. O., \& Oloyede, O. B. (2011). Physico-chemical properties and fatty acid composition of C. esculentus (Tiger nut) tuber oil. Biores Bull., 5, 51-54.

Oderinde, R. A., \& Tairu, O. A. (1988). Evaluation of the properties of yellow nutsedge (Cyperus esculentus) tuber oil. Food Chemistry, 28(3), 233-237. http://dx.doi.org/10.1016/0308-8146(88)90055-6.

Oladele, A. K., \& Aina, J. O. (2007). Chemical composition and functional properties of flour produced from two varieties of tiger nut. African Journal of Biotechnology, 6(21), 2473-2476. http://dx.doi. org/10.5897/AJB2007.000-2391.

Özcan, M. M., Gümüşçü, A., Er, F., Arslan, D., \& Özkalp, B. (2010). Chemical and fatty acid composition of Cyperus esculentus. Chemistry of Natural Compounds, 46(2), 276-277. http://dx.doi.org/10.1007/ s10600-010-9586-5.

Phillips, K. M., Ruggio, D. M., \& Ashraf-Khorassani, M. (2005). Phytosterol composition of nuts and seeds commonly consumed in the United States. Journal of Agricultural and Food Chemistry, 53(24), 9436-9445. http://dx.doi.org/10.1021/jf051505h. PMid:16302759.

Püskülcü, H., \& İkiz, F. (1998). Introduction to statistic. Bornova: Bilgehan Press. In Turkish. 
Sánchez-Zapata, E., Fernández-Lopez, J., \& Pérez-Alvarez, J. A. (2012). Tigernut (Cyperus esculentus) commercialization: Health aspects, composition, properties, and food applications. Comprehensive Reviews in Food Science and Food Safety, 11(4), 366-377. http:// dx.doi.org/10.1111/j.1541-4337.2012.00190.x.

Shaker, M. A., Ahmed, M. G., Amany, M. B., \& Shereen, L. N. (2009). Chufa tubers (C. esculentus L.): as a new source of food. World Applied Sciences Journal, 7(2), 151-156.

Skujins, J. (1998). Handbook for ICP-AES: a short guide to vista series ICP-AES operation. Version 1-0. Switzerland: Varian International AG Zug.

Temple, V. J., Ojebe, T. O., \& Kapu, M. M. (1989). Chemical analyses of tiger nut (Cyperus esculentis). Journal of the Science of Food and Agriculture, 49, 261-262. http://dx.doi.org/10.1002/jsfa.2740500214.

Türk Standartları Enstitüsü. (2014). TS EN ISO 520:2014: oil seeds: determination of 1000 seed weight. Ankara.
Uylaşer, V., \& Başoğlu, F. (2000). Gıda analizleri 1-2: uygulama kilavuzu. Bursa: Uludağ Üniversitesi Yayınları. In Turkish.

Vázquez-Oderiz, M. L., Vazquez-Blanco, M. E., Lopez-Hernandez, J., Simal-Lozano, J., \& Romero-Rodriguez, M. A. (1994). Simultaneous determination of organic acids and vitamin $\mathrm{C}$ in gren beans by liquid chromatography. Journal of AOAC International, 77(4), 1056-1059. PMid:8069112.

Yeboah, S. O., Mitei, Y. C., Ngila, J. C., Wessjohann, L., \& Schmidt, J. (2012). Compositional and structural studies of the oils from two edible seeds: tiger nut, Cyperus esculentum, and asiato, Pachira insignis, from Ghana. Food Research International, 47(2), 259-266. http://dx.doi.org/10.1016/j.foodres.2011.06.036.

Yoon, S. H. (2015). Physical and chemical characteristics of chufa (Cyperus esculentus L.) oils extracted from chufa tubers grown in the midportion of Korea. Food Science and Biotechnology, 24(6), 2027-2029. http://dx.doi.org/10.1007/s10068-015-0268-8. 